\title{
A Loco-weed New to Canada Found at Canopus, Saskatchewan
}

\author{
by JOHN H. HUDSON, Regina
}

While botanizing in the RockglenKilldeer country last summer, I saw a smali (about $10 \mathrm{~cm}$. high) silvery loco-weed with a short (3-6 cm.) spike of splendid magenta flowers growing on outcrops of the buff facies of the Ravenscrag formation (mostly yellow silt).

I took a sample (Hudson No. 1825) from a butte south of Canopus in NE 1/4 3-3-2 W3rd, on June 18, 1956.

The plant did not fit the description of any species known to occur in Saskatchewan; it was near Oxytropis lambertii of the Estevan-Oxbow country, but this latter is a much bigger plant $20-40 \mathrm{~cm}$. high with a long spike (10-20 cm.) of magenta flowers. So it was a question of sending a specimen out for expert determination; but before this, fruiting material had to be located. I therefore revisited the spot at Canopus on August 26 and learned with surprise that the plant in seed was hard to find, as the pods dropped off prompt ly cn ripening. I managed to get on plant and a few spare pods (Hudso No. 1911).

Flowering specimens and a po were sent to Rupert C. Barneby, th legume expert. He named it Oxyiro pis besseyi (Rydb.) Blank, an said that this was the first record $\mathrm{fr}$ Canada. The nearest known statio was in Dawson County, Montan: some 140 miles southeast. The decid uous legume was, he added, nearl characteristic of $O$. besseyi.

One more point may be noted; th lcco was strictly confined to outcror of the buff facies of the Ravenscra fcrmation, and none was seen out side of the driftless area describe by Widkenden as extending betwee Rockglen and Killdeer. Dawso Ccunty, Montana, (around Glendive lies beyond the uttermost limit continental glaciation. Is this just coincidence?

\section{Additions to the Flora of Manitoba}

\author{
By GEORGE A. STEVENSON, \\ Dominion Experimental Farm, Brandon, Manitoba
}

As a hobby during the past five or six years I have collected plants in and around Brandon, Manitoba. Most collections were made within the city limits. Some of these were new to the province at the time of collection and it has been suggested that I publish a list of the names so that a permanent record might be obtained.

Alopecurus myosuroides Huds. 1955. Cultivated land.

Eragrostis megastachya (Koeler.) Link. 1950. Grassed area, Provincial Exhibition Grounds.

Eremopoa persica (Trin.) Roshev. 1955. Ballast.

Setaria verticillata (L.) Beauv. 1949. Garden and cultivated soil.

Juncus compressus Jacquin. 1950. Marshy land west of city.

Vicia villosa Roth. 1953. Grassland. Lamium album L. 1956. Old perennial border.
Plantigo media L. 1953. Grassed are and edge of roadway, Provinci: Exhibition Grounds.

$\mathrm{X}$ Bidens stevensonis Boivin. 195 Wooded ravine and banks of $A s$ siniboine. $B$ cernua and $B$. vulgat the putative parents are commo in the district.

$\mathrm{X}$ Cypripedium andrewsii A. M. Fu. ler. 1954. Growing on low prairj among $C$. parviflorum and $C$ : ca ceolus, the putative parents.

Among the plants sent in $c$ brought in to the Experimental Farr for identification recently two appec to be first records for the province Echium vulgare L. var pustulatu? - (Sibth. \& Sm.) Coincy. 195 Growing in ballast at Alexande Plantago indica L. 1955. Found in garden somewhere in Manitob Unfortunately there is no record. the location or the collector's nam 